\title{
Cross Cultural and Cultural Counseling: Komunikasi Konseling Lintas Budaya Jawa dan Madura di Madrasah Aliyah Negeri 1 Jember
}

\author{
Suryadi \\ Intitut Agama Islam Negeri Jember \\ S2lazuvya@gmail.com
}

\begin{abstract}
Penelitian ini bertujuan untuk menemukan model komunikasi efektif antara peserta didik yang berlatar belakang budaya Madura dengan peserta didik yang berlatar belakang budaya jawa. Penelitian ini menggunakan metodologi kualitatif dengan menyusun, memahami dan menganalisis model komunikasi peserta didik yang berlatar belakang budaya Madura dengan peserta didik yang berlatar belakang budaya jawa di Madrasah Aliyah Negeri (MAN) 1 Jember. Model komunikasi peserta didik dari budaya Madura dengan Jawa dipengaruhi oleh kultur bahasa dari atmosfer lingkungan yang berbeda. Dari sini terlihat bagaimana proses layanan konseling yang inklusif dan ramah berjalan melalui pendekatan transcultural menjadi langkah yang dilakukan oleh guru BK atau konselor Madrasah guna meminimalisir adanya gesekan sosila yang pernah terjadi pada peserta didik beretnis Jawa dengan peserta didik beretnis Madura.
\end{abstract}

Kata Kunci: Cross Cultural, Cultural Counseling, Komunikasi, Siswa, Madrasah.

\begin{abstract}
This research aims to find the model of effective communication between students with Madurese cultural backgrounds and students with Javanese cultural backgrounds. This research uses qualitative methodology by compiling, understanding and analyzing the communication model of students with Madurese cultural backgrounds and students from Javanese cultural backgrounds in State Madrasah Aliyah (MAN) 1 Jember. The communication model
\end{abstract}


of students from Madura culture with Java is influenced by language culture from different environmental atmospheres. From this it can be seen how the process of inclusive and friendly counseling services running through a transcultural approach is a step taken by BK teachers or Madrasah counselors in order to minimize the existence of social friction that has ever occurred to Javanese students with Madurese ethnic students.

Keywords: Cross Cultural, Cultural Counseling, Communication, Students, Madrasa.

\section{A. Latar Belakang}

Bimbingan dan konseling adalah usaha memberikan bantuan kepada seseorang agar mampu mengarahkan potensi dirinya berkembang secara optimal dengan proses yang memandirikan. Di Indonesia sendiri layanan bimbingan dan konseling diberikan secara massif pada lembaga pendidikan formal. Hal ini yang menunjukkan bahwa layanan bimbingan dan konseling sangat penting dan utama dalam membantu proses perkembangan peserta didik, kaitannya dengan proses mengarahkan potensi pada diri individu secara optimal dan mandiri, selain membantu seorang konseli dalam menyelesaikan masalah yang dihadapinya.

Dalam konteks ke-Indonesia-an, maka yang menjadi ciri khasnya adalah karakter Indonesia masuk kedalam ranah bimbingan dan konseling. Misalnya pancasila yang notabene adalah falsafah Negara Indonesia masuk kedalam proses bimbingan dan konseling menjadi landasan bimbingan dan konseling itu sendiri. Dalam landasan yuridis atau landasan hukumnya pun undang-undang yang ada di Indonesia juga menjadi dasar dari bimbingan dan konseling itu sendiri.

Indonesia Memiliki banyak keragaman baik suku, budaya, dan agamanya tidak menutup kemungkinan adanya perbedaanperbedaan dalam proses bimbingan dan konseling. Baik perbedaan dari konselor terhadap konseli, atau konseli terhadap konseli yang lain. hal inilah yang melatar belakangi lahirnya konseling lintas budaya di Indonesia.

Dalam konseling lintas budaya banyak hal yang bisa dikaji baik dari hal komunikasi, perbedaan budaya, perbedaan kebiasaan 


\section{Cross Cultural and Cultural Counseling: Komunikasi Konseling ...}

dari seorang individu maupun kelompok. Di jawa Timur terdapat dua suku dan budayanya yang cukup vocal mewarnai kehidupan masyarakatnya.Suku dan budaya tersebut adalah suku jawa sendiri dan suku Madura " diantara kedua suku tersbut juga terdapat suku osing, suku samin, dan suku tengger".Kedua suku dan budaya tersebut dengan segala karakternya mempunyai sebuah keunikankeunikan tersendiri di mata peneliti.

Dalam membincangkan dua budaya atau lebih " atau yang sering kita sebut kajian lintas budaya cross culture" maka hal yang sangat sering didiskusikan adalah bagaimana komunikasi antara satu budaya dengan budaya lain itu berjalan. Begitu juga dalam pembahasan komunikasi konseling lintas budaya.Makah hal yang unik dan penting diteliti adalah bagaimana konektivitas antara beberapa budaya tersebut berjalan ber-proses.

Salah satu keunikan kedua suku dan budaya tersebut adalah terletak pada sebuah gaya dan bentuk komunikasinya. Dalam suku dan budaya Jawa karakter masyarakatnya dan manusianya memberikan gaya bahasa dan komunikasinya yang unik sesuai dengan daerah-daerah. Misalnya kota Jember bahasa atau kalimat yang digunakan sering menggunakan dengan kalimat yang unik. Contohnya kata minum bisa diganti dengan ngombeh, dan banyak kalimat-kalimat yang lain sebagainya.

Kota Jember yang letaknya berada di Ujung timur pulau Jawa mempunyai keunikan tersendiri di dalam bahasa.Dimana ada dua bahasa yang digunakan di daerah tersebut, bahasa Madura dan bahasa jawa.Jember selatan seperti ambulu, uluhan, kencong dan balung semua masyarakatnya menggunakan bahasa jawa.Dan jember lainnya patrang, mangli, arjasa, rambipuji dan daerah lainnya selain selatan jember mayoritas masyarakatnya dalam kesehariannya berkomunikasi dengan menggunakan bahasa Madura.

Selain bentuk atau sifat komunikasi verbal tersebut tentunya banyak keunikan-keunkan tersendiri dari komunikasi di masyarakat Jawa "Khusunya di daerah Jember" yang dilihat dari ranah non verbalnya atau bentuk komunikasi yang lain. misalnyagesture dan lantangnya suara dalam komunikasi.

Sedangkan dari suku dan budaya Madura juga memberikan keunikan-keunikan tersendiri. Misalnya suara keras, bentuk atau 
gesture yang serius dan tegang, serta banyak lain yang memberikan ciri khas lain. kotradiksi menarik tersebutlah yang melatarbelakangi penulis untuk melakukan penelitian ini. Dimana kotradiksi tersebut harus dicerna, ditelaah, dan ditelisik dengan baik oleh seorang konselor dalam memberikan layanan bimbingan dan konseling lintas budaya, terutama konteksnya pada ranah komunikasi konseling lintas budaya di MAN 1 Jember.

Adanya kontradiksi karakter yang melekat dalam kedua background etnis tersebut tentunya akan membawa rintangan dan hambatan dalam berkomunikasi. Rintangan dan hambatan tersebut bisa terjadi karena beberapa faktor, faktor tersebut antara lain faktor pribadi, faktor fisik, dan faktor bahasa. Jika komunikasi terdapat rintangan dan hambatan tentunya akan mempengaruhi lancer dan efektifnya kegiatan konseling, khususnya konseling lintas budaya. Tentunya hal ini harus disikapi dan dicarikan solusi agar hal tersebut bisa teratasi dengan baik.

\section{B. Pembahasan}

\section{Bimbingan dan Konseling Lintas Budaya}

Bimbingan dan konseling lintas budaya adalah bimbingan dan konseling jika terjadi perbedaan antara konselor dengan konseli dari segi budayanya. Perbedaan budaya tersebut bisa terjadi berbeda bahasa komunikasinya baik verbal maupun nonverbal, kebiasaan dan adatnya, maupun perbedaan yang lain.

Dalam konseling lintas budaya, budaya atau kebudayaan meliputi tradisi, kebiasaan, nilai-nilai, norma-norma, bahasa, keyakinan, dan pola berpikir dalam suatu masyarakat dan diwariskan dari generasi ke generasi serta memberikan identitas pada komunitas pendukungnya (Putra 2013:1). Batasan konseling lintas budaya terletak pada hubungan konseling antara dua peserta ataupun lebih yang memiliki latar belakang yang berbeda serta gaya hidup yang berbeda juga (Masturi 2015).

Dilihat dari identitas budaya, konseling lintas budaya meruapakan hubungan konseling budaya yang berbeda antara konselor dan konseli. Hal ini juga dipertegas oleh Burn menjelaskan cross cultural counseling is the process of counseling individuals who are of different culture/cultures than that of the therapist. Oleh sebab 


\section{Cross Cultural and Cultural Counseling: Komunikasi Konseling ...}

itu menurutnya konselor terhadap bimbingan dan konseling lintas budaya sangat penting.Ia menegaskan:

Its this important of counselors to be sensitive to and considerate of a clients cultural makeup. Clinican encounter many challenging and complex issues when attempting to provide accesimble, effective, respectful and culturally affirming chemical dependency treatment to a multicultural population of deaf and hard of hearing individuals (Materi PLPG Sertifikasi Guru Pada Tahun 2009. n.d.).

Konseling lintas budaya adalah pelbagai hubungan konseling yang melibatkan para peserta yang berbeda etnik atau kelompokkelompok minoritas, atau hubungan konseling yang melibatkan konselor dan konseli yang secara rasial dan etnik sama, tetapi memiliki perbedaan budaya yang dikarenakan variabel-variabel lain seperti seks, orientasi seksual, faktor sosio-ekoonomik dan usia (Casmini 2014).

Konseling lintas budaya bisa di artikan atau disebut dengan berbagai istilah.Konseling antar budaya, konseling muti kulturalisme, atau konseling multi budaya. Dalam konseling lintas budaya atau multi budaya, hasil-hasil yang akan dicapai tidak boleh dihalangi oleh perbedaan-perbedaan budaya konselor dan konseli. Tentunya asumsi filosofis yang sering dinyatakan sebagai keberhargaan dan martabat yang melekat pada individu, penghargaan atas keunikan pribadi.

Dalam bidang konseling dan psikologi, pendekatan lintas budaya dipandang sebagai kekuatan keempat setelah pendekatan psikodinamik, behavioral dan humanistik.Suatu masalah yang berkaitan dengan lintas budaya adalah bahwa orang mengartikannya secara berlain-lainan atau berbeda, yang mempersulit untuk mengetahui maknanya secara pasti atau benar.Dapat dinyatakan, bahwa konseling lintas budaya telah diartikan secara beragam dan berbeda-beda; sebagaimana keragaman dan perbedaan budaya yang memberi artinya. Definisi-definisi awal tentang lintas budaya cenderung untuk menekankan pada ras, etnisitas, dan sebagainya (Carter, RT 1991: 164-173). 
Untuk mencapai atau mewujudkan keberhasilan konseling lintas budaya, seorang konselor harus bergerak menuju pengejaran aktif fondasi teoritis yang tepat dan praktik-praktik yang efektif. Seorang konselor harus mengenali dan memahami berbagai budaya serta keunikan yang dimiliki oleh para klien atau konseli.

Terdapat beberapa pendekatan dalam konseling lintas budaya dan agama. Pendektan tersebut antara lain adalah pertama, pendekatan universal atau etik yang menekankan inklusivitas, komonalits atau keuniversalan kelompok-kelompok. Kedua, pendekatan emik atau kekhususan budaya yang menyoroti karakteristik-karakteristik khas dari populasi-populasi spesifik dan kebutuhan-keutuhan konseling khusus.Ketiga, pendekatan inklusif atau transcultural; keterlibatan dalam konseling merupakan proses yang aktif dan resiprokal (Robert L. Gibson 2011:320).

Dalam praktik konseling lintas budaya prosesnya juga menggunakan tahapn-tahapan konseling secara umum, karenan tahapn-tahapan ini nantinya juga sangat penting. Tahapan tersebut adalah proses Attending, mendengarkan, bertanya, empati, pemusatan, klarifikasi, membuka diri, memberi dukungan, memberi dorongan, pemecahan masalah, dan yang terakhir adalah proses menutup pembicaraan.

\section{Urgensi Komunikasi Konseling Lintas Budaya Terhadap Konseli dan Konselor}

Komunikasi sangatlah erat hubungannya dengan kehidupan kita, namun terkadang kita masih kesulitan jika ditanya tentang definisi dari kata tersebut. Stephen W. Littlejohn mengatakan bahwa; communication is define, the word is abstract and like most term, posses numerous meaning "komunikasi sulit untuk didefinisikan, kata komunikasi bersifat abstrak, seperti kebanyakan istilah memiliki banyak arti (Morissan 2013:4).

Ada yang secara jelas menjelaskan arti komunikasi, diantaranya adalah definisi dari Keith Davis, mengemukakan bahwa" communication is the transfer of information and understanding from one person to another person. Sedangkan Edwin berpendapat "communication is the act of inducing others to interpret and idea in the manner intended by the speaker or writer". Bahwa komunikasi adalah aktivitas yang menyebabkan orang lain menginterprestasikan 


\section{Cross Cultural and Cultural Counseling: Komunikasi Konseling ...}

suatu ide, terutama yang dimaksudkan oleh pembicara atau penulis (Negara n.d.:143).

Dalam bukunya Andrew E. Sikula memberikan definisi komunikasi sebagai berikut, "communication is the process of transmitting information, meaning, and understanding from one person, place, or thing another person, place, or thing". Komunikasi adalah proses pemindahan informasi, pengertian dan pemahaman dari seorang, suatu tempat, atau sesuatu kepada sesuatu, tempat atau orang lain.

Komunikasi didefinisikan sebagai apa yang terjadi bila makna diberikan kepada suatu perilaku. Bila seorang memperhatikan perilaku kita dan memberinya makna, komunikasi telah terjadi terlepas dari apakah kita menyadari perilaku kita atau tidak menyengajanya.Bila kita memikirkan hal ini, kita harus menyadari bahwa tidak mungkin bagi kita tidak berkomunikasi (Schramm 2010:13).

Selanjutnya definisi komunikasi lintas atau antar budaya adalah jika terjadi saat anggota dari stu budaya tertentu memberikan pesan kepada anggota dari budaya yang lain. lebih tepatnya komunikasi antar budaya melibatkan interaksi antara orang-orang yang berpersepsi budaya dan sistem simbolnya cukup berbeda dalam satu komunikasi.

Bentuk komunikasi lintas budaya bisa berupa perbedaan bahasa, perbedaan kebiasaan, perbedaan agama, perbedaan agama dan hukum. Masing-masing individu atau kelompok pasti melekat dengan khas apa yang menjadi keunikan dan karakteristik masingmasing. Hal inilah yang menjadi garapan komunikasi lintas budaya tersebut. Bahwa komunikasi lintas budaya akan saling mempertemukan dan menyapakan antara entitas satu dengan entitas lainnya, sehingga terjadi interaksi didalamnya. Tentunya komunikasi akan menjalankan tugasnya secara sistematis.

Jadi, dari beberapa pengertian komunikasi menurut tokoh diatas penulis dapat menyimpulan bahwa secara sederhana komunikasi dapat dimaknai atau didefinisikan sebagai usaha atau tindakan seseorang untuk berinteraksi atau berhubungan dengan lingkungan sekitar "individu dengan individu, individu dengan kelompok, atau kelompok dengan kelompok".Serta komunikasi juga 
dapat dimakanai sebuah alat untuk saling berhubungan dengan maksud dan tujuan tertentu, semisal komunikasi antar agama ataupun anatar budaya.

\section{Komunikasi Sebagai Inti Dalam Pemberian Layanan Konseling Lintas Budaya}

Komunikasi sebagai inti dalam pemberian layanan konseling lintas budaya hal ini bisa dijelaskan karena dalam memberikan layanan konseling lintas budaya, unsur komunikasi adalah sebagai jantung dari proses konseling. Jika konselor memiliki kemampuan berkomunikasi secara efektif maka komunikasi akan memberikan beberapa effect dan influence dalam proses konseling.

Konselor yang memiliki kepribadian yang baik dalam berkomunikasi secara baik dan efektif maka komunikasi tersebut dapat dijadikan alat dan senjata utama dalam bimbingan dan konseling lintas budaya. Komunikasi tersebut dijadikan alat untuk; a) Membuka dan mengawali konseling, b) Mengumpulkan merangkum dan membantu mencari solusi atas persoalan psikologis yang sedang dihadapi klien, c) Menunjukkan respon positif sehingga konseli merasa aman dan nyaman serta merasa diterima dengan baik, d) Mengembangkan kualitas kesehatan mental konseli, e) Mengembangkan perilaku lebih efektif pada diri konseli terhadap lingkungan, f) Membangun rasa percaya diri dalam menanggulangi problem hidup konseli sehingga pada akhirnya bisa mandiri, g) Dunia bimbingan konseling salah satu bahasanya adalah komunikasi.Komunikasi dalam bimbingan dan konseling sendiri mencakup dua komponen, yakni; komunikasi verbal dan komunikasi non verbal.Seorang konselor harus memiliki kecakapan komunikasi verbal maupun non verbal.

\section{a. Komunikasi Verbal}

Komunikasi verbal adalah komunikasi antara komunikan dan komunikator dengan medium atau media dengan ucapan yang bisa didengarkan secara langsung atau dengan menggunakan kata-kata.

Dalam referensi lain dikatakan bahwa setiap pesan yang disampaikan melalui kata-kata disebut dengan pesan verbal. Dalam sebuah hubungan, pesan verbal sangat penting dalam perkembangan sebuah hubungan.Tidak terbayangkan bagaimana sebuah hubungan dapat berkembang bila satu dengan lainnya tidak saling berbicara.Di 


\section{Cross Cultural and Cultural Counseling: Komunikasi Konseling ...}

sinilah pentingnya sebuah komunikasi verbal dalam sebuah layanan bimbingan dan konseling (Wisnuwardhan and Mashoedi 2012:49).

Nilai nilai komunikasi dalam ajaran agama Islam sendiri terdapat beberapa ajaran komunikasi itu sendiri.Bahwa komunikasi, khususnya komunikasi verbal harus meliputi nilai komunikasi yang Qoulan Sadidan "komunikasi secara jujur", Qoulan Balighan "komunikasi secara efektif" Qoulan Masyuuran "komunikasi secara rasional" Qoulan Layyinan "berkomunikasi dengan kata-kata penjelas atau tepat" Qoulan Kariman "berkomunikasi dengan kompetensi" dan Qoulan Ma'ruufan "komunikasi sesuai dengan etika (Syahputra 2007:145).

Teknik yang dilakukan dalam bimbingan dan konseling kaitannya dengan komunikasi verbal maka yang digunakan kebanyakan adalah teknik konseling langsung.Di sini bisa mengandalkan wawancara atau percakapan secara verbal.

Komunikasi verbal dalam konseling lintas budaya menggunakan komunikasi verbal itu sendiri untuk dijadikan sebuah alat konseling.Teknik konseling verbal adalah teknik konseling verbal semabarang. Hal ini sesuai dengan apa yang diungkapkan oleh njang AS sebagai berikut;

Tanggapan verbal yang diberikan konselor merupakan perwujudan konkrit dari maksud, pikiran, dan perasaan yang terbentuk dalam batin konselor, untuk membantu konseli pada saat tertentu.Wawancara konseling terdiri atas rangkaian ungkapan dari konseli yang disusul oleh ungkapan si konselor. Dengan demikian akan membentuk suatu mata rantai, dimana setiap mata rantai terdiri dari suatu ungkapan konselor dan konseli. Ungkapan konselor berupa tanggapan verbal untuk maksud menolong konseli dengan menggunakan satu atau lebih teknik verbal, tergantung dari intensitas konselor (Enjang AS 2001:50).

\section{b. Komunikasi Non Verbal}

Komunikasi melibatkan tidak hanya proses verbal yang berupa kata, fase atau kalimat yang diucapkan dan didengar, tetapi juga proses non verbal. Proses non verbal meliputi isyarat, ekspresi wajah, kontak mata, postur dan gerakan tubuh, sentuhan, pakaian, 
artefak, diam, temporalitas, dan ciri parangualistik (Mulyana 2013:68).

Komunikasi non verbal adalah proses komunikasi di mana pesan disampaikan bukan menggunakan dengan kata-kata. Contoh komuikasi non verbal adalah gerak isyarat, bahasa tubuh, ekspresi tubuh, dan kontak mata, serta intonasi suara.

Bahasa komunikasi non verbal meliputi ekprsi wajah, tahapan mata, gerakan tubuh, sentuhan, jarak interpersonal, parabahasa. Jadi dalam komunikasi konseling non verbal akan memberikan data dan fakta secara otentik. Karena hal ini disebabkan tidak biasanya manipulasi dalam gesture konseli atau konselor.Layaknya komunikasi dengan verbal atau ucapan yang dapat memanipulasi kata-kata secara lisan (Wisnuwardhan and Mashoedi 2012:43).

Bebrbicara komunikas non verbal adalah berbicara isyarat dan simbol.Dasar perilaku non verbal menjadi isyarat yang reliable sebagai sikap pandang seseorang karena mereka nampaknya menjadi "pembicara" internasional.Lintas budaya secara umum orang mengakui petunjuk non verbal dari senang atau tidak senang, suka atau tidak suka, tegang atau rileks serat status tinggi atau status rendah (Putra 2013:87).

Perilaku bawaan seperti senyum dan tangisan ini dapat diartikan dan dinilai. Seperti senyum secara umum dikenali sebagai tanda dan makan keakraban, mempunyai arti lain yang khusus pada suatu budaya.

Fungsi dari komunikasi non verbal adalah sebagai berikut; a) Menggantikan pesan percakapan 'replacing spoken mesanges', b) Pengiriman pesan yang tidak enak 'sending uncomfortable message', c) Membentuk kesan yang memadu komunikasi 'forming impressions thay guide communication', d) Membuat hubungan yang bersih'making relationship clear'e) Mengatur interaksi 'regulation relationship', f) Penguatan dan memodifikasi pesan verbal 'reinforcing and modifying verbal messages'

Hal lain yang harus diperhatikan oleh konselor dalam memperhatikan komunikasi non verbal adalah macam-macam bentuk komunikasi non verbal, macam-macam tersebut adalah; Pertama, Proxemics, elemen bahasa non verbal yang secara sosial 


\section{Cross Cultural and Cultural Counseling: Komunikasi Konseling ...}

diakui dan digunakan oleh masyarakat sebagai bagian dari bahasa verbal yang tak terpisahkan. Bahasa sosial ini sangat tergantung pada latar belakang kultural seseorang. Misalnya adalah peserta didik berlatar belakang etnis Madura mempunyai volume suara yang keras, sedangkan peserta didik berlatar belakang etnis jawa lebih memiliki volume suara yang agak pelan. Ini bisa diartikan dalam komunikasi non verbal yang melekat pada komunikasi verbal. Bahwa volume keras mempunyai arti yang harus dimaknai oleh konselor.

Kedua, Kinesics, analisis khusus terhadap bahasa tubuh. Bahasa tubuh ini terdiri dari muka atau wajah, gerak-gerik bagian tubuh yang lain seperti bahu, tangan, kaki, serta bagian tubuh yang lain yang dapat mengisyaratkan arti tertentu. Misalnya untuk menghargai lawan bicaranya masyarakat Madura sering menundukkan muka dan pandangan matanya. Sedangkan masyarakat Jawa sering membungkukkan badan serta menaruh tangan di depan badan dengan menumpuknya dengan memperlihatkan lawan bicara.

Ketiga, Paralanguage, adalah segala bentuk suara vokal tetapi non verbal. Suara vokal ini termasuk kualitas suara, cara-cara pengekspresian bahasa verbal, dan suara-suara yang non verbal seperti tertawa dan menangis yang tidak dikomunikasikan melalui suara akan tetapi terkandung dalam kata-kata yang ada dalam bahasa verbal tersebut. Contoh peserta didik berlatar belakang etnis Jawa mengekspresikan rasa bahagianya dengan senyum-senyum sendiri, sedangkan sering peserta didik berlatar belakang etnis Madura mengekpresikan rasa bahagianya tak sedikit dengan ekpresi tangisan baru.

Dalam konteks lintas budaya resistensi dan tidak adanya kesamaan pandangan dan maksud akan besar terjadi. Hal ini dikarenakan bahwa tidak benarnya penerimaan maksud dari satu orang ke orang lain. setephen P. Robinson mengatakan;

"komunikasi merupakan alat yang bebas nilai. Bisa membawa manfaat, bisa juga membawa mudharat, tergantung dari yang menggunakannya.Bahkan komunikasi sendiri bisa menjadi pemicu konflik, terutama kalau tidak diperhatikan dengan sungguh-sungguh kekhasan-kekhasan budaya.Komunikasi dalam budaya yang dikenal berknteks 
rendah misalnya berbeda dari kmunikasi dalam budaya berkonteks tinggi.Dalam budaya berkonteks tinggi tekanan diberikan pada petunjuk-petunjuk non verbal situasional.Apa yang tidak dikatakan. Sementara dalam budaya dalam konteks rendah lebih ditekankan kata untuk menyampaikan arti, yang penting adalah kata yang diucapkan atau ditulis" (Ujan 2009:103).

\section{Peserta Didik Berlatar Belakang Etnis Jawa}

Masyarakat jawa adalah masyarakat yang sangat mempunyai nilai keagungan budayanya.baik budaya yang diejahwantahkan dalam kesenian dan tradisi maupun nilai-nilai yang dilakukan dalam kehidupan sehari-hari.Masyarakat jawa juga terkenal dalam kesantunan dan kelembutannya. Tingkat kualitas sumber daya manusianya juga baik dibandingkan daerah-daerah lain dinegeri ini.

Hal tersebut banyak terpengaruh dari pusat pemerintahan Indonesia di Jawa yang menjadikan daerah yang komplit akan fasilitas-fasilitas yang dapat mendukung setiap masyarakat yang ada di daerah jawa. Pendidikan sangatlah memiliki dampak yang signifikan bagi perkembangan kualitas masyarakat kita.

Di jawa timur sendiri adalah daerah terbesar ke dua setelah Ibu kota Republik Indonesia yaitu provinsi DKI Jakarta, disini kaulitas dan sarana fasilitas pendidikan sangatlah maju dan mapan. Mulai dari pendidikan usia dini, pendidikan kanak-kanak, MTs atau SMP, Madarasah Aliyah dan berbagai perguruan tinggi baik negeri maupun swasta tumbuh subur di Provinsi paling timur pulau jawa.

Melakukan konseling seorang konselor madrasah menggunakan kalimat-kalimat verbal campuran bahasa jawa dengan bahasa Indonesia. Hal ini dilakukan mulai dari proses attending, proses bertanya dan mendengarkan sampai akhir. Peneliti berasumsi mengapa guru BK menggunakan campurn bahasa Jawa dalam melakukan konseling terhadap peserta didik berlatar belakang etnis jawa.Hal ini untuk mempermudah agar peserta didik merasa nyaman dan diterima dengan baik oleh konselor.

"proses attending adalah pintu masuk atau langkah awal yang sangat mempengaruhi jalannya konseling sampai akhir. Jika attending yang dilakukan guru BK baik maka 


\section{Cross Cultural and Cultural Counseling: Komunikasi Konseling ...}

akan semakin mudah guru BK menjalankan tugasnya. Dalam memberikan layanan konseling kepada peserta didik beretnis jawa maka seorang guru harus "sumeh" dan dibarengi dengan kata-kata verbal bahasa jawa yang bersifat friendly kepada peserta didik."

Dari situlah maka pentingnya memasukkan unsur-unsur budaya, dalam hal ini bahasa verbalnya, demi lancarnya proses konseling itu sendiri. Walaupun bahasa Indonesia-lah yang dianjurkan dalam kegiatan belajar di madrasah, namun hal ini tidak dilarang, karena sifatnya lebih memberikan manfaat kepada peserta didik itu sendiri, baik rasa nyaman dan aman karena diberikannya rasa empati oleh konselor madrasah dengan komunikasi menggunakan bahasa jawa.

Dalam Islam juga diperintahkan untuk berkomunikasi dengan menggunakan pilihan kata yang tepat agar diperoleh efek seperti yang diharapkan. Untuk menjaga dan memberikan kemudahan kepada peserta didik dalam berkomunikasi, maka tidak salah dipilih kata-kata yang tepat yakni dengan menggunakan bahasa jawa dengan maksud agar proses konseling berjalan dengan efekti.pendekatan secara non verbal juga perlu dilakukan agar supaya peserta didik yang berlatar belakang etnis jawa akan merasa nyaman dan dihormati jika seorang konselor menerima dan berkomunikasi dengan bahasa tubuh yang memiliki muatan-muatan norma budaya jawa yang mereka pahami.

Pendekatan dan metode yang digunakan dalam memberikan konseling kepada peserta didik yang berlatar belakang etnis jawa adalah dengan menggunakan pendekatan cultural dengan budaya jawa. Hal ini menunjukkan bahwa dalam melakukan proses interaksi atau komunikasi konseling dengan peserta didik yang memiliki background etnis Jawa, guru bimbingan dan konseling menggunakan pendekatan emik. Dengan memperhatikan kekhasan tersebut maka konseling komunikasi akan mengalir dengan lancer dan meminimalisir adanya halangan atau hambatan dalam memberikan konseling kepada peserta didik. 


\section{Peserta Didik Berlatar Belakang Etnis Madura}

Permasalahan yang dialami oleh peserta didik berlatar belakang etnis Madura misalnya adalah suka ramai jika di dalam kelas, atau volume suara dalam berbicara sering terlalu keras, dan pada akhirnya menganggu peserta didik yang lain. kebiasaan yang sering menimbulkan permasalahan peserta didik di MAN 1 Jember adalah peserta didik berlatar belakang etnis Madura sering bersikap semaunya sendiri tanpa memperhatikan lingkungan sekitar (Suyatno 2017).

Seorang konselor ketika berkomunikasi dengan peserta didik yang memiliki etnis Madura, meraka banyak menggunakan bahasa non verbal.Bahasa non verbal sangatlah penting untuk para konselor madrasah untuk memberikan layanan konseling kepada peserta didik berlatar belakang etnis Madura, hal ini disebabkan tidak mempuninya konselor madarasah dalam menggunakan bahasa Madura.

Pernyataan tersebut menunjukkan pentingnya tanda dan symbol non verbal akan Nampak bila orang dari suatu budaya berkomunikasi dengan orang dari budaya lain. meskipun mereka berbicara bahasa yang sama mereka mungkin mengalami keslah pahaman ketika mereka salah memahami atau menafsirkan perilaku non verbal tertentu yang mengisyaratkan perilaku non verbal tertentu.

Symbol-simbol tersebutlah yang harus diperhatikan oleh konselor madrasah guru $B K$ untuk mengejahwantahkan kondisi peserta didik yang sebenarnya.Tentunya juga harus dibarengi dengan perkataan verbal, baik sesuai dengan bahasa Madura juga.Hal inilah dalam Islam sudah disebutkan bahwa seorang konselor harus mempunyai konsep komunikasi dengan Qoulan Balighan, artinya berkomunikasi secara efektif, tepat sasaran dan tujuan.Konselor sebagai komunikan menggunakan bahasa yang sesuai dengan bahsa konseli sebagai komunikan.

Pendekatan yang digunakan juga adalah komunikasi kultural yang digunakan untuk mendekati peserta didik beretnis Madura. Hal ini karena kebiasaan masyarakat Madura jika didudukkan dan berdialog dengan landasan sama-sama membawa budaya Madura 


\section{Cross Cultural and Cultural Counseling: Komunikasi Konseling ...}

maka seribet apapun masalah akan selesai. Oleh sebab itu komunikasi baik verbal, non verbal maupun pendekatan budaya akan sangat mempengaruhi proses konseling.

\section{Perbedaan dan Persamaan Pelayanan Komunikasi Konseling}

Etnis Madura sebenarnya adalah bagian sub etnis Jawa.Hal tersebut dikarenakan letak geografis pulau Madura yang ada di wilayah Jawa Jawa imur.Namun dalam kehidupan sehari-harinya dua etnis ini memiliki berbagai perbedaan dan persamaan.Etnis Madura tersebar ke seluruh pelosok negeri ini.Di Jawa timur sendiri etnis Madura terdistribusi banyak di daerah Jember, Bondowoso, Situbondo, probolinggo, dan lumajang.

Di Jember sendiri terdapat Komunitas etnis Madura yang sangat besar.Etnis Madura tumbuh subur dan pesat di daerah Jember selain Jember selatan.Termasuk sekolah MAN 1 Jember yang dijadikan objek penelitian adalah kawasan yang mayoritasnya dihuni oleh masyarakat Madura. Hal ini juga berdampak pada banyaknya peserta didik yang mempunyai latar belakang etnis Madura di MAN 1 Jember. Karakter-karakter khas antara peserta didik berlatar belakang etnis jawa dengan etnis Madura harus diperhatikan secara baik-abaik dan teliti olehguru BK di MAN 1 Jember. Hal inilah yang akan peneliti paparkan hasil temuan di lapangan mengenai perbedaan dan persamaan komunikasi konseling yang diterapkan oleh guruk BK terhadap peserta didik yang berlatar belakang etnis Jawa dan Madura.

\section{a. Perbedaan Etnis Jawa Dengan Etnis Madura}

Pertama, perbedaan bahasa verbal yang dilakukan konseling dalam memberikan layanan konseling, konselor madrasah menggunakan bahasa jawa untuk peserta didik yang berlatar belakang etnis jawa. Dan menggunakan bahasa Indonesia untuk peserta didik yang berlatar belakang etnis Madura.

Kedua, Dari bahasa komunikasi non verbalnya terdapat perbedaan antara peserta didik berlatar belakang etnis jawa dengan peserta didik berlatar belakang etnis Madura.Gestureyang diberikan oleh kedua etnis tersebut antara Jawa dan Madura sangat berbeda, misalnya masyarakat peserta didik berlatar belakang etnis Madura yang bernada keras dan cepat dapat melakukan sesuatu membawa karakter sendiri, sedangkan peserta didik yang berlatar belakang 
etnis Jawa yang agak sedikit lembut dan halus dalam berucap dan tindakannya sedikit lebih santun juga membawa penafsiran yang jeli oleh guru BK di MAN 1 Jember.

Ketiga, adalah peserta didik yang kesulitan dalam menggunakan komunikasi bahasa Indonesia maka guru Bk meminta bantuan kepada personil lain yang dapat komunikasi dengan bahasa Madura.

\section{b. Persamaan Etnis Jawa Dengan Etnis Madura}

Selain perbedaan dari konseling lintas budaya disini juga terdapat beberapa persamaan komunikasi yang diterapkan guru BK pada peserta didik yang berlatar belakang etnis Jawa dan etnis Madura. Pertama, seluruh konselor madrasah menggunakan bahasa Indonesia sebagai bahsa formal yang berlaku di lingkungan madrasah. Walaupun dalam prakteknya saat konseling bahsa tersebut akan campur-campur dengan bahasa Jawa dan Madura (Suyatno 2017). Kedua, pendekatan ampuh yang digunakan untuk melakukan konseling dan dapat melancarkan jalannnya konseling adalah sama-sama menggunakan pendekatan culture.

\section{Simpulan}

Disini sangat terlihat bahwa untuk memberikan layanan konseling yang inklusif atau ramah kepada berbagai etnis yang ada di MAN 1 Jember kabupaten Jember etnis Madura dan etnis jawa.Pendekatang dengan transkultur maka akan memberikan jembatan dari adanya perbedaan dan persamaan antara konseli yang mempunyai latar belakang etnis Madura dengan konseli yang memiliki latar belakang etnis Jawa.

Pendektan transcultural dapat menjadi problem solver adanya kontradiksi dua budaya yang ada di MAN 1 Jember. Hal ini dapat juga dilakukan dengan baik oleh guru BK atau konselor Madarsah guna meminimalisir adanya gesekan sosila yang pernah terjadi pada peserta didik beretnis Jawa dengan pserta didik beretnis Madura.Pendekatan ini memberikan pendektan yang win-win solution dalam konteks komunikasi konseling lintas budaya di madarasah. 


\section{DAFTAR PUSTAKA}

Carter, RT ,1991. Cultural Values: A Review of Empirical Research and Implications for Counseling. Journal of Counseling \& Development. 70: 164-173.

Casmini, 2014. Bimbingan Dan Konseling Lintas Agama Dan Budaya", ,. Paper presented at the dipresentasikan dalam kegiatan kuliah, Pasca Sarjana UIN Sunan Kalijaga Yogyakarta.

Enjang AS, 2001. Komunikasi Konseling, Dari Wawancara, Seni Mendengar, Sampai Soal Kepribadian. Bandung: Penerbit Nuansa.

Masturi, 2015. Counselor Encapsulation:"Sebuah Tantangan Dalam Pelayanan Konseling Lintas Budaya", vol.Vol. 1. No. 2. Jurnal Konseling GUSJIGANG.

Materi PLPG Sertifikasi Guru Pada Tahun 2009. N.d.

Morissan 2013 Teori Komunikasi. Bogor: Ghalia Indonesia.

Mulyana, Dedy 2013 Metodologi Penelitian Kualitatif; Paradigma

Baru Ilmu Komunikasi Dan Ilmu Sosial. Bandung: PT Remaja Rosda Karya.

Negara, Anwar Prabu Mangku N.d. Manajemen Sumber Daya Manusia Perusahaan. Bandung: PT. Remaja Rosda Karya.

Putra, Anak Agung Ngurah Adi 2013. Konseling Lintas Budaya. Yogyakarta: Graha Ilmu.

Robert L. Gibson 2011 Bimbingan Dan Konseling. Yogyakarta: Pustaka Pelajar.

Schramm, Wilbrum 2010. Komunikasi Antar Budaya, Panduan

Berkomunikasi Dengan Orang-Orang Berbeda Budaya.

Bandung: PT. Remaja Rosdakarya.

Suyatno, Agus 2017,Hasil Wawancara. April 27.

Syahputra, Iswandi 2007, Komunikasi Profetik. Bandung: Simbiosa Rekatama Media.

Ujan, Andre Ata, 2009. Multikulturalisme; Belajar Hidup Bersama Dalam Perbedaan,. Jakarta: PT. Indeks.

Wisnuwardhan, Dian, and Siti Fatmawati Mashoedi, 2012. Hubungan Interpersonal. Jakarta: Salemba Humanika. 